\title{
Arachidonate 12-Lipoxygenase, 12S-Type
}

National Cancer Institute

\section{Source}

National Cancer Institute. Arachidonate 12-Lipoxygenase, 12S-Type. NCI Thesaurus. Code C103926.

Arachidonate 12-lipoxygenase, 12S-type (663 aa, $76 \mathrm{kDa}$ ) is encoded by the human ALOX12 gene. This protein plays a role in both fatty acid oxidation and leukotriene biosynthesis. 